\title{
A game theory of organizational ecology : a model of managerial inertia and market selection
}

Citation for published version (APA):

van Witteloostuijn, A., \& Boone, C. A. J. J. (1997). A game theory of organizational ecology : a model of managerial inertia and market selection. NIBOR, Netherlands Institute of Business Organization and Strategy Research. NIBOR Research Memorandum No. 05 https://doi.org/10.26481/umanib.1997005

Document status and date:

Published: 01/01/1997

DOI:

10.26481/umanib.1997005

Document Version:

Publisher's PDF, also known as Version of record

\section{Please check the document version of this publication:}

- A submitted manuscript is the version of the article upon submission and before peer-review. There can be important differences between the submitted version and the official published version of record.

People interested in the research are advised to contact the author for the final version of the publication, or visit the DOI to the publisher's website.

- The final author version and the galley proof are versions of the publication after peer review.

- The final published version features the final layout of the paper including the volume, issue and page numbers.

Link to publication

\footnotetext{
General rights rights.

- You may freely distribute the URL identifying the publication in the public portal. please follow below link for the End User Agreement:

www.umlib.nl/taverne-license

Take down policy

If you believe that this document breaches copyright please contact us at:

repository@maastrichtuniversity.nl

providing details and we will investigate your claim.
}

Copyright and moral rights for the publications made accessible in the public portal are retained by the authors and/or other copyright owners and it is a condition of accessing publications that users recognise and abide by the legal requirements associated with these

- Users may download and print one copy of any publication from the public portal for the purpose of private study or research.

- You may not further distribute the material or use it for any profit-making activity or commercial gain

If the publication is distributed under the terms of Article $25 \mathrm{fa}$ of the Dutch Copyright Act, indicated by the "Taverne" license above, 
A game theory of organizational ecology: A model of managerial inertia and market selection

A. van Witteloostuijn \& C. Boone

NIBOR/RM/97/05

http://www.unimaas.nl/ document/fdewb.htm

J.E.Lit. code: L21

$n i b \circ r$

Netherlands Institute of

Business Organization

and Strategy Research

University of Maastricht

Faculty of Economics and Business Administration

P.O. Box 616

6200 MD Maastricht

The Netherlands

Phone: ++31 43 - 3883805 


\title{
A GAME THEORY OF ORGANIZATIONAL ECOLOGY \\ A Model of Managerial Inertia and Market Selection
}

\section{Arjen van WITTELOOSTUIJN and Christophe BOONE}

Faculty of Economics and Business Administration

\author{
NIBOR (Netherlands Institute of Business Organization and Strategy Research) \\ University Maastricht \\ Department of Management Sciences \\ P.O. Box 616 \\ 6200 MD Maastricht \\ The Netherlands \\ Phone: (43) 883806 \\ Fax: (43) 258495 \\ E-mail: A.vanWitteloostuyn@MW.Unimaas.NL
}

We gratefully thank Glenn Carroll for his helpful comments. This paper is really the result of a cooperative effort. For the sake of variety, and to neutralize the consequences of the current citation analysis practices, we have the routine to randomize the order of the authors' names over our joint papers. 


\title{
A GAME THEORY OF ORGANIZATIONAL ECOLOGY A Model of Managerial Inertia and Market Selection
}

\begin{abstract}
This paper merges two theoretical perspectives in a mathematical game model: industrial organization on the one hand, which basically is the economic theory of market competition and firm strategies, and organizational ecology on the other, which is a major sociological tradition that studies the evolution of organizational populations. The merger is instrumental in analyzing a key question in organization studies: what is the role of flexibility, inertia and efficiency in facilitating firm performance in a selection environment, in terms of both profitability and survival? Particularly, we argue that game theory can offer a mathematical model of organizational ecology. Such a game-theoretic model reveals that an inert firm may push a flexible rival from the market, even if the inert market leader faces a cost disadvantage. Moreover, this may happen in a munificent environment. That is, cut-throat rivalry can be the result of strategic competition only - being facilitated by organizational inertia. This paper operationalizes relative inertia by modeling managerial resistance against downsizing. The model clearly supports the key claim of organizational ecology that relative inertia facilitates rather than impedes survival chances.
\end{abstract}




\section{INTRODUCTION}

Organizational ecology (OE) is a sociological theory of what happens to and within populations of organizations. OE has produced an impressive and still rapidly increasing number of empirical studies (Baum, 1996). For example, the number of studies that have tested density-dependence hypotheses reaches infinity. No doubt, the empirical tradition that has been established by $\mathrm{OE}$, is an important enrichment of organization sciences. In recent years, a cry for increased theoretical precision has emerged, however. For example, Baum (1996: 107-108) concludes his impressive review of OE with a plea for such precision with reference to the need for "asking new kinds of research questions that develop links with other streams in organization theory". We believe that the organizational subdisciplines within economics are specifically promising in this respect. Here we fully agree with Amburgey \& Rao (1996: 1280), who in a recent special issue of the Academy of Management Journal observe that organizational economics is one area of overlap with OE that remains to be explored. This is precisely what this paper does. In effect, we merge OE with the dominant subbranche of industrial organization (IO): game theory. We strongly believe that the mathematical tools of game theory are particularly applicable to OE-issues. That is, the very nature of game theory makes this modeling technique well-suited to explore the impact of between-firm (or between-population) differences in inertia on direct competition and ultimately on firm performance and survival.

Thematically, this paper confronts the standard 'flexibility and efficiency favor selection' logic with OE-reasoning. Carroll \& Harrison (1993: 92) summarize the efficiency-favorssurvival story line by arguing that "[t]his logic holds, first, that when an organizational form emerges and spreads, it is because of the form's efficiency and, secondly, that when an organizational form disappears, it is because of its inefficiency" (Carroll \& Harrison, 1993: 92). In a similar vein, advocates of the strategic choice theory argue that flexibility helps a firm to survive in a competitive environment. The theoretical originality of $\mathrm{OE}$ comes from the counterintuitive argument that this standard story may not hold true. This is reflected in Hannan \& Freeman's (1984) well-known inertia theory. However, the theory of the consequences of inertia on survival is still in need of much refinement. In effect, the relationships between relative inertia, organizational size and firm survival are highly complex and ill-understood (Hannan \& Freeman, 1989). The current paper presents a game-theoretic model that goes into this complicated issue.

So, the main purpose of this paper is to mark a first step into analyzing the inertiaselection nexus, particularly the consequences of inertia on the survival of organizations, through a mathematical theory of OE. To achieve this aim, we adopt a research strategy that is new in the context of OE. More specifically, we will show that important insights on this issue can be gained by inserting the crucial OE-concept of inertia into a game-theoretic model of competition. Game theory is by now gaining popularity in strategic management, as two special issues of the Strategic Management Journal (in 1988 and 1991) indicate. To our knowledge, game theory - being the hard core of the economic tradition in modern industrial organization (Tirole, 1988) - has as yet not been applied to central OE-issues. From the very 
nature of game theory, being a mathematical tool to analyze strategic interaction in a competitive setting, we believe that this approach is particularly suited to develop a mathematical foundation of OE. Here, we complement Péli, Bruggeman, Masuch \& Nualláin's (1994) application of first-order logic.

In the first section we stress the potential synergies which can be realized by crossfertilizing the insights from OE with the framework of game-theoretic industrial organization. Then, we summarize the inertia debate so as to set the scene for presenting three thoughtprovoking propositions that follow from inertia-related reasoning. The next section introduces the essentials of a game-theoretic Cournot model that incorporates a manifestation of organizational inertia, particularly managerial resistance against downsizing, in a selection framework. In addition, a number of counterintuitive results of the model will be presented. An appraisal and selection of further research issues conclude the paper.

\section{ORGANIZATIONAL ECOLOGY AND INDUSTRIAL ORGANIZATION}

We have argued elsewhere that the potentials for cross-fertilization between OE and IO are substantial (Boone \& Van Witteloostuijn, 1995). The reason is that understanding the dynamics of industry evolution is an important research issue in both $\mathrm{IO}$ and OE. Moreover, OE incorporates economic concepts such as competition, and often reveals a resemblance to economic analysis. Surprisingly enough, such a cross-fertilizing endeavour has - as yet - not been undertaken. In our view, this lack of cross-fertilization may well be caused by a key misunderstanding of the merits of IO-research, as expressed in important OE-contributions. ${ }^{1}$

The misunderstanding resides in the fact that since the 1970s much IO-literature has been dominated by the application of game theory to rivalry in oligopolistic markets (Tirole, 1988). Apparently, the results of this applied game theory tend to depend critically upon the assumptions underlying the game model at hand (Shapiro, 1989; and Sutton, 1991). Hannan \& Carroll (1992: 22) comment that "[t]he analytic results apparently lack robustness". The critique is that IO-scholars have therefore focused their research efforts on specific markets, which allow for adaptation of the oligopoly model to the idiosyncrasies of the specific setting. Of course, this 'ultra-micro work' (Sutton, 1991: 6) impedes understanding of the observed statistical regularities over industries. This observed lack of robustness is one of the main reasons why cross-fertilization between IO and OE has not yet occurred (Hannan \& Carroll, 1992). The implied characterization is, however, partly besides the mark. For example, theoretical and empirical regularities abound in a number of key contributions to the Handbook of Industrial Organization (Schmalensee \& Willig, 1989), examples being the monopolizing impact of commitments (Gilbert, 1989) and the thirty empirical regularities that have emerged from industry studies (Schmalensee, 1989). Particularly the work of Sutton

\footnotetext{
${ }^{1}$ The following argument overemphasizes the IO-OE contrast by purposely ignoring the grey zone between IO's 'black' and OE's 'white'. A clear example of a grey-zone theory is Carroll's (1985) resource-partitioning framework. Boone \& Van Witteloostuijn (1995) offer a detailed review of this promising grey zone.
} 
(1991) is a convincing case in point. Sutton (1991) proves in his masterpiece that game theory can be applied to develop robust predictions on the level of industry concentration, which hold across a wide class of reasonable models (and thus allow application to a broad set of different industries).

Setting aside this misunderstanding, game-theoretic modeling may contribute significantly to OE for three reasons. The first reason relates to differences in the analytical tools that are as a routine! - applied to explicate theories of IO and OE. ${ }^{2}$ Modern IO-theory is mainly based on formal mathematical modeling, whereas OE's foundation is carried by 'natural language'. It is clear that "[i]nconsistency, incoherence, or other defects in logic are difficult to detect when a theory is stated in natural language" (Péli, Bruggeman, Masuch \& Ó Nualláin, 1994: 571). In this respect, it is interesting to note that in the above-quoted paper Hannan \& Freeman's article 'Structural inertia and organizational change' (1984) is formalized in first-order logic, which enabled the discovery of a number of logical defects in the latter's theory of inertia. Obviously, mathematical modeling is one way to avoid such logical defects.

Secondly, and more important, competition is a central concept in both $1 O$ and OE. It is fair to say, however, that the theoretical elaboration of the concept and process of competition in $\mathrm{OE}$ is rather limited. OE recognizes that two forms of competition can be distinguished: indirect and direct competition (Barnett \& Amburgey, 1990; and Hannan \& Carroll, 1992). Indirect or diffuse competition arises from the fact that actors influence each other because they compete for the same limited resources (Hannan \& Carroll, 1992). In other words, "[s]uch competition occurs when organizations reduce another's viability by depleting a limited common supply of resources" (Barnett \& Amburgey, 1990: 80). Note that diffuse competition does not require any social ties between actors. In addition, competitive constraints exist whether or not the actors recognize their interdependence as competitors. Direct competition implies mutual recognition of the salience of the competitive moves of other actors, and is therefore tantamount to conflict or rivalry (Hannan \& Carroll, 1992). Until now, OE-research has mainly focused on diffuse competitive processes. As Hannan \& Carroll (1992: 190) comment, "[o]ur arguments in this book emphasized diffuse competition, processes that link the life chances of organizations that may or may not interact as direct competitors by, for instance, taking into account each other's actions as rivals. Instead of trying to measure the intensity of diffuse competition, we used arguments about competitive processes to develop implications for the relationship between density and the vital rates of organizational populations". In our view, a theory which is mainly based on processes of competition and legitimation should incorporate both diffuse and direct competition. In this respect, 10 is very informative as economic theory has a long tradition of describing and modeling many (implications of) different types of competition - ranging from perfect (diffuse) competition to oligopolistic (direct) competition (Tirole, 1988; and Fudenberg \& Tirole, 1991).

Thirdly, although Hannan \& Freeman's (1984) argument that selection favors inertia is thought-provoking, the theory on the consequences of inertia (and organizational change) on

\footnotetext{
${ }^{2}$ Does the OE-argument apply to the evolution of sciences - interpreted as populations of paradigms or theories - as well? A nice case would be the OE-paradigm itself.
} 
survival is still in its infancy. In effect, the relationships between relative inertia, organizational size, change and survival appear to be highly complex and ill-understood (Hannan \& Freeman, 1989). As Hannan \& Freeman (1989: 90) comment, "[o]rganizational selection operates on many dimensions besides reproducibility of structure. If selection pressures on specific features of structure are sufficiently strong, organizations with the characteristics appropriate to the environment are favored even if they have low levels of reproducibility. By the same token, environments in which change is turbulent and uncertain may not constitute a systematic regime of selection; the traits that are favored may shift frequently enough that no clear trend emerges. Such settings may favor organizational forms that can take quick advantage of new opportunities. The capacity to respond quickly to new opportunities presumably competes with the capacity to perform reliably and accountably". ${ }^{3}$

Apart from this fundamental consideration, inertia theory is limited in scope as it neglects the likely influence of inertia on the degree of direct competition between organizations within the same population. Recall that inertial pressures stem from a variety of external and internal constraints (Hannan \& Freeman, 1977), such as investment in capacity or any other sunk cost, organizational history or culture, limits on the internal information received by decision makers, and (sunk) entry and exit barriers (Hannan \& Freeman, 1977; and Haveman, 1993). Game-theoretic modeling on strategic competition suggests that firms consciously manipulate inertia-increasing strategic moves in order to deter entry and to alleviate direct competition. A nice example is the commitment notion (Dixit, 1982; and Ghemawat, 1991): only irreversible investment - which by the definition of commitment implies reduced flexibility - can operate as a credible strategic move. A second, and related, case in point is the incurement of endogenous sunk costs, such as advertising outlays, to build up market share (Sutton, 1991). Sutton (1991) shows that the competitive escalation of advertising outlays forces second-tier firms to exit and may, eventually, generate a dual industry structure with a few leading firms and a large number of small, specialized and nonadvertising firms. The key point is that 10 has an open eye for the commitment-flexibility trade-off (Spencer \& Brander, 1992). This paper's model, too, has something to say on this trade-off issue by allowing for the calculation of an 'optimal' degree of flexibility or inertia. But before going into the model, we first summarize the inertia debate.

\section{THE INERTIA DEBATE}

\section{The inertia argument}

The central tenet in the strategic management literature is that incumbent firms should

\footnotetext{
${ }^{3}$ It should be mentioned, however, that empirical OE-research consistently shows that mortality rates are higher for smaller and younger as opposed to larger and older organizations [liability of smallness and liability of newness, respectively; see Singh \& Lumsden (1990) for a review]. As it is generally accepted that inertia increases with organizational size and age (Kelly \& Amburgey, 1991), these findings offer at least indirect evidence for the selectionfavors-inertia argument. However, other explanations can account for these findings as well, such as market power and organizational slack (Haveman, 1993). Note, moreover, that the age-size-mortality linkage may be a statistical artefact (Barron, West \& Hannan, 1994).
} 
change their strategies and structures so as to adopt organizational 'blueprints' (Hannan \& Freeman, 1977) which facilitate flexibility. For instance, firms should replace their 'bureaucratic blueprint' with a 'network blueprint'. An illustrative case in point are studies on organizational decline suggesting that 'strategic paralysis' (D'Aveni, 1989a), which is a manifestation of inert strategic behavior, foreshadows organizational failure. Broadly speaking, two important assumptions are (implicitly) made by adherents of the adaptation (or strategic choice) model of organizational change: (1) organizations are able to implement such radical transformations with success; and (2) flexibility increases profitability and ultimately survival chances. This typical twin of assumptions is clear from standard text books in strategic management such as Johnson \& Scholes (1993). The validity of both strategic choice assumptions, however, can be questioned. ${ }^{4}$

The first assumption is not realistic according to the organizational ecology theory of organizations (OE). OE argues that organizations are hard pressed to adjust their 'blueprint' as they feature relative inertia: that is, they lag behind changes in the environment (Hannan \& Freeman, 1984). This is not to say that organizations never change, but rather that adjustments are rare and appear only after significant delays. So, organizations tend to be inert relative to environmental turbulence. Additionally, OE suggests that organizational change, if possible at all, does increase the failure rate. The reason is that the impact of changing the core features of an organization is equivalent to creating a new organization. As a consequence, "[o]rganizational change tend[s] to 'reset the clock', exposing the organization once again to the 'liability of newness'" (Swaminathan \& Delacroix, 1991: 681). Indeed, a number of scholars observed that failure rates increased after organizations implemented major structural changes (Freeman \& Hannan, 1990; Haveman, 1990; and Amburgey, Kelley \& Barnett, 1993). The bottom line is that "[a]s the large number of regularly occurring organizational failures indicates, adaptation models are limited in their abilities to explain organizational change" (Carroll \& Harrison, 1993: 93). OE therefore argues that organizational change follows mainly from the replacement of one organizational blueprint with another, rather than through adaptation of individual organizations (Hannan \& Freeman, 1989; and Carroll \& Harrison, 1993).

The second assumption is based on the general retrospective economic rationality argument, as commonly applied to the rise and fall of organizational forms (Carroll \& Harrison, 1993). This is the argument that efficiency facilitates firm performance and survival, whereas the opposite holds true for inefficiency. Nowadays, for instance, the new network forms of organization are deemed to be highly efficient - due to their flexibility - compared to the old 'bureaucratic blueprint' organizations. In our view, such an assumption is somewhat precarious. Although an increasing number of authors speculates that the 'dynamic network organization' will be the main organizational form in the twenty-first century (Miles \& Snow,

\footnotetext{
${ }^{4}$ Of course, many contributions to the strategic management literature, particularly those concerned with the processes of strategic decision making, emphasize the viscidity of organizational manoeuvring, a case in point being Quinn's (1978) logical incrementalism. However, the very purpose of strategic management is to adapt to environmental circumstances. This is the benchmark case that we confront with the organizational ecology perspective. Hrebiniak \& Joyce (1985) and Frederickson \& laquinto (1989) are but two examples of arguments that reflect on the flexibility-inertia debate in the strategic management literature.
} 
1984; and Dyer \& Ouchi, 1993), until now virtually nothing is known about the circumstances that promote and sustain network forms (Miles \& Snow, 1992). We agree with Powell (1990: $327)$ that "[a] good deal more research is needed on the durability of networks". To be sure, we do not suggest that efficiency and flexibility are not important. However, we oppose against the simplistic argument that flexibility is the only key to efficiency and (thus) to organizational survival.

In this respect, again, OE offers a very informative opposing benchmark. As already mentioned above, relative inertia (i.e., the opposite of flexibility) is a central concept in the Darwinian selection theory of OE (Hannan \& Freeman, 1989; and Boone \& Van Witteloostuijn, 1995). The argument of relative inertia implies that the outside world selects organizational blueprints, and that the dynamics of diversity can be understood by focusing on the founding and mortality rates of those blueprints. Moreover, OE posits that inertia is not only a precondition for Darwinian selection, but - even more important - also a consequence (Hannan \& Freeman, 1984). In other words, selection favors organizational forms characterized by relatively inert structures. The underlying logic runs as follows (Hannan \& Freeman, 1984). First, organizations have to be reliable: organizations can only be reliable suppliers of goods and services if they operate on the basis of routines that guide their functioning. Second, organizations have to be accountable for their activities and performance. Accountability also requires stable rules and procedures. Third, organizational reliability and accountability can only be guaranteed if organizational structures are highly reproducible. The routines, rules and procedures determining reliability and accountability must stay in place over time. Selection pressures will work in this direction: hence, rigid and viable blueprints are selected (Boeker, 1988).

The effects of reliability, accountability and reproducibility cumulate into the argument that "[t]he modern world favors collective actors that can demonstrate or at least reasonably claim a capacity for reliable performance and can account rationally for their actions. So it favors organizations over other kinds of collectives and favors certain kinds of organizations over others, since not all organizations have these properties in equal measure. Selection within organizational populations tends to eliminate organizations with low reliability and accountability. ... Thus we assume that selection in populations of organizations in modern societies favors forms with high reliability of performance and high levels of accountability" (Hannan \& Freeman, 1989: 74). Apparently, we are left with an intriguing contradictory view on the consequences of inertia (or flexibility). Blending the assumptions of the strategic choice framework and OE suggests that firms are faced with a complex dilemma: that is, they need to be flexible and inert at the same time in order to survive in the long run (see also Burgelman, 1991). Moreover, this trade-off points to the possible existence of an 'optimal' level of inertia (or flexibility). Unfortunately, hardly any systematic research has been done on the central tenets of both research strands.

\section{Managerial inertia}

Broadly speaking, inertia can operate at three levels of analysis: the system (or population), the organizational and the managerial level. System inertia may be the result of the existence 
of path dependencies in the competitive process - defined as the situation where prior decisions, choices or actions affect current and future behavior of the system (Carroll \& Harrison, 1993). In the case of technology, for instance, "[p]ath dependence can occur when adoption of a given technology contains advantages because of the previous number of adopters" (Carroll \& Harrison, 1993: 92). Such path dependence may lead to the peculiar result that inferior technologies - such as the QWERTY typewriter keyboard, the color television system in the U.S., and the VHS recording technology - become and remain dominant despite of the availability of more efficient alternatives (Carroll \& Harrison, 1993). Note that this concept of path dependence is borrowed from the economic theories of network externalities (Katz \& Shapiro, 1985 \& 1986; and Farrell \& Saloner, 1986). That is, switching costs at the demand side, which result from network economies, may impede firms from introducing superior technologies. Other examples of inertia at the population level are industry exit and entry barriers.

Organizational inertia relates to variations in the force of inertia among organizations within the same population. For instance, such variations may be the result of organizational size and age differences (Hannan \& Freeman, 1989) or differences in capital intensity. Another source of variation may be the well-established phenomenon of resistance to change on an organization's work floor, as treated in each text book on organizational behavior (such as Robbins, 1993). Related to organizational inertia is the observation that inertia may also operate at the level of key actors - or the dominant coalition - within the organization (Hannan \& Freeman, 1989). In this respect, Hannan \& Freeman's (1989: 67-68) reference to internal politics is particularly revealing: "internal politics contribute to inertia. Altering structures upsets political equilibria. When resources controlled by an organization are fixed, structural change requires reallocating resources among subunits; so at least some subunits are likely to resist any proposed reorganization. ... Any negative political response will generate shortrun political costs that may be high enough that decision makers will forgo the planned reorganization" (emphases added). This paper focuses on the ultimate reorganization: downsizing. Then, downsizing comes with high political costs through resistance from those organizational participants - work floor and management - who are confronted with retrenchment, whereas expansion tends to be received with applause by those who may grow.

This argument is translated into the assumption that a manager of a firm maximizes a combination of profit and sales, which implies a deviation from orthodox profit-maximizing behavior. In this paper, we focus on one specific form of asymmetric managerial inertia: that is, key actors, on the one hand, like to manage growing firms in terms of sales and, on the other hand, hate to downsize. Specifically, this preference implies asymmetric inertia, as the positive utility from sales growth impedes the management's incentive to downsize but increases the management's willingness to expand, even if this implies that profit is sacrificed. So, on the one hand, a 'growth-loving manager' is willing to accept that increases in sales volume come at the expense of profit. Moreover, on the other hand, the 'downward' inertia implies a cost of change in the sense that a reduction of sales volume produces a disutility for the management of the firm. 
The empirical validity of this crucial behavioral assumption is firmly established in organizational research. Here a number of interesting studies have appeared in both the economic and sociological literature. On the issue of sales growth motives Scherer \& Ross (1990: 50), for example, argue that "[although executive salaries and bonuses are correlated with both firm size and the level of profits, the size correlations tend to be the stronger of the two. Consequently, executives might be willing to sacrifice profitability at the margin to enhance sales and hence compensation" (emphasis added). Similarly, the well-known industrial organization theorist Tirole (1988: 34-35) points to "a widespread feeling that in practice ... managers have other objectives (e.g., maximizing the firm's size and growth and the perquisites of the managerial position). ... For instance, the shareholders' incomplete information ... may allow the managers to inflate the need for personnel" (emphases added). This "feeling" is since long recognized in the organization sciences literature, as is clear from the classic work on goal conflict by Cyert \& March (1963) and the continuing attention to motivational and goal setting issues in text books on organizational behavior (Robbins, 1993) and strategic management (Johnson \& Scholes, 1993).

From an empirical angle cumulative evidence supports the claim that pure profit maximization does not characterize firms. Two branches of literature are particularly worth mentioning here. First, direct tests of managers' objectives in the tradition of managerial economics have revealed that profit maximization alone does not guide managerial behavior. Two early examples of direct evidence on the sales maximization hypothesis are Hall (1967) and Lackman \& Craycroft (1974). Peck (1988) reports the results of a survey into corporate objectives among 1,000 American and 1,031 Japanese top managers: two findings are that increasing market share ranks third in the American and second in the Japanese subsample, whereas return on investment is first among American and third among Japanese top managers. Second, indirect evidence comes from studies of managerial behavior in the context of principal-agent arguments. A large number of studies into managerial compensation, in both $1 \mathrm{O}$ and organization sciences literatures [two recent examples being Jensen \& Murphy (1990) and Lambert, Larcker \& Weigelt (1991), respectively] have revealed that executive bonuses and salaries are associated with both firm size and profit level, with the size correlations being the stronger of the two. The importance of sales growth as a motivation for management is also supported by evidence on the explanation of 'bad' acquisitions (Shleifer \& Vishny, 1988; and Morck, Shleifer \& Vishny, 1990). Evidence from organization sciences contributions, too, cearly indicates that managers prefer volume. Particularly, studies of firms' growth point out that "growth is frequently sought directly because it facilitates the internal management of an organization" (Whetten, 1987: 30).

\section{Three inertia-related propositions}

As was explained above, from an OE-perspective the key argument is that relative inertia facilitates organizational survival. We will now formulate three propositions that may follow from this OE-argument. Here, the general nature of our propositions is specified to fit with this paper's model by operationalizing the key elements in parentheses. First, the OE's inertia theory suggests that day-to-day profit-maximizing behavior is counterproductive, since such 
guiding principle is closely related to flexibility. With profit-maximizing behavior, a firm adapts its processes, structures and strategies in function of emerging profit opportunities. This is the standard argument in the neo-classical (IO) theory of the firm (Holmstrom \& Tirole, 1989). All that a firm is doing, is meant to adapt to changing circumstances in order to maximize profitability. Agency theory fits in this tradition, too. In the end, agency modeling retains the ultimate firm objective of profit maximization, albeit taking into account such complexities as information costs and incentive structures. In the context of the current paper, the standard IO-argument is that a firm will move its production volume up and down with increasing and decreasing aggregated market demand so as to maximize its profitability. ${ }^{5}$ Here, Holmstrom \& Tirole (1989: 103) argue that "incentives should not be connected with quantity choice and the profit maximization paradigm remains valid in spite of agency problems". In OE-reasoning, this implies the type of flexibility that reduces the firm's reliability and reproducibility, and so survival chances. In the retrenchment context of the current paper, the argument may be that work floor motivation and operational routines break down through downsizing (Pfeffer, 1994). Basically, OE argues that selection may operate on many other dimensions than pure profitability alone. In this context, Hannan \& Freeman (1989: 20) even set aside optimization reasoning as a viable route for explaining selection processes. In the context of the current paper, the OE-argument implies that nonprofit-maximizing behavior as a result of managerial resistance against downsizing may help the firm in its battle for selection. This argument induces Proposition 1.

PROPOSITION 1. A profit-maximizing (i.e., managerially inert) firm may well be outcompeted by a nonprofit-maximizing (i.e., flexible) rival. In the extreme, the latter firm may even survive at the expense of the former.

Proposition 1 is a clear example of an OE-argument that goes against any traditional IOintuition. This counterintuitive line of reasoning can be extrapolated further by introducing the role of efficiency.

As was already indicated above, a popular argument in much organization sciences literature is that efficiency facilitates a firm's profitability and, thus, survival chances. In effect, this argument dominates 10 -economics for centuries now through the heavy emphasis on the analysis of perfect competition. The current magnum opus of 10 in this respect are the theories of perfect contestability (Baumol, Panzar \& Willig, 1982) and industry structure (Panzar, 1989), which prove mathematically why and how cost efficiencies determine entry and exit processes as well as industry structure equilibria. These theories are consistent with the assumption of standard economic theory which postulates that, given natural selection, profit-maximizing and thus efficient firms will survive and, hence, dominate in reality (Alchian,

\footnotetext{
${ }^{5}$ Again, there is more in $\mathrm{IO}$ than this standard argument, examples being the models that take account of commitment strategies and adjustment costs. However, all these addenda to the standard story still assume profit maximization to be the firm's decision rule. For the sake of clarity, we ignore these subtleties.
} 
1950; Friedman, 1953; and Machlup, 1967). ${ }^{6}$ Again, applying OE-reasoning may produce a different prediction. That is, if the drive for efficiency introduces the need for changing structures, processes and strategies, the downside of reduced inertia may dominate the immediate benefit of cost decreases. ${ }^{7}$ Here, Hannan \& Freeman (1989: 34) refer to the necessity to correct the "overemphasis of the role of efficiency considerations" in organization sciences. In effect, they (1989: 339) argue that "[a]lthough we recognize that considerations of efficiency have powerful consequences for many kinds of organizations, we feel that they do not obviously override institutional and political considerations". Proposition 2 relates to this argument.

PROPOSITION 2. An efficient (i.e., low-cost) but profit-maximizing (i.e., flexible) firm may well be outcompeted by an inefficient (i.e., high-cost) but nonprofit-maximizing (i.e., managerially inert) rival. In the extreme, the latter firm may even survive at the expense of the former.

So, Proposition 2 introduces the inefficiency-may-survive argument on top of Proposition 1's prediction as to the viability of nonprofit-maximizing (managerially inert) behavior.

Propositions 1 and 2 really oppose OE-reasoning with traditional strategic choice and IOpredictions. However, there is a literature that emphasizes that this apparent 'or'-story really is a matter of 'and'. That is, it may well be that a firm must seek flexibility and inertia, rather than either of the two. An example of this argument is Burgelman (1991), pointing out that an organization should combine an inert core with a flexible pheriphery as this combination permits the firm to be reliable without loosing its ability to adapt. This type of reasoning suggest that there is an 'optimal' degree of what we may call 'flexertia'. From a contingency perspective, we assume that this optimal degree of flexertia depends upon environmental contingencies. For example, flexibility may dominate in young and high-tech industries, whereas inertia may be crucial in old and low-tech markets. Proposition 3 strikes this middle ground.

PROPOSITION 3. Depending upon a number of environmental contingencies (i.e., carrying capacity, cost level and the rival's decision rule), an optimal (i.e., 'profit-maximizing') degree of (i.e., managerial) 'flexertia' can be calculated.

\footnotetext{
${ }^{6}$ Winter (1975) opposes against this argument. With Nelson he developed an alternative framework: evolutionary economics (Nelson \& Winter, 1982). This theory emphasizes the role of organizational routines, which is a concept akin to OE's relative inertia. However, in the evolutionary economics argument changing routines - and hence organizational adaptation - still impedes failure rates. Therefore, the divergence from economic rationality reasoning is only a matter of degree. For the sake of brevity, evolutionary economics is ignored here. Winter (1990) relates this theory to OE.

${ }^{7}$ This argument illustrates that the notions of profit-maximization, flexibility and efficiency are intricately related. Theoretically, all combinations are thinkable (e.g,. a nonprofit-maximizing but efficient firm). However, introducing these subtleties in this paper would unneccessarily complicate the argument.
} 
Proposition 3 describes what we may call the profit-maximization paradox. To maximize its profitability it may be that a firm should behave as if decision making is guided by nonprofitmaximizing rules. We will discuss the interpretation of this paradox in the next section, from both OE and IO-perspectives. Together, Propositions 1 to 3 are clear examples of the counterintuitive predictions that may follow from OE-related reasoning. This paper provides a theoretical underpinning of such OE-related hypotheses by developing a mathematical game theory in which (non)profit maximization, (in)efficiency and selection are introduced so as to prove all three propositions in a competitive Cournot setting. It is to this model that we now turn.

\section{A GAME-THEORETIC MODEL}

\section{Model structure}

The model introduces direct strategic competition in the form of a Cournot duopoly: two incumbent firms compete over output by deciding on the supply volume they offer to the demand side of the market. Detailed accounts of the model, including all proofs and results, are presented in Van Lier \& Van Witteloostuijn (1993). The key issue in Proposition 1 is that nonprofit-maximizing behavior may facilitate survival. Therefore, the model builds on a specific class of game-theoretic models which explores the consequences of nonprofit-maximizing firm behavior in a competitive setting. Particularly interesting (game-theoretic) models in this tradition are presented by Vickers (1985), Fershtman \& Judd (1987) and Sklivas (1987). ${ }^{8}$ In all these papers, firms are assumed to have sales (growth) next to profit objectives, which introduces an element of organizational size and departs from the extreme rationality postulate commonly imposed in orthodox game-theoretic contributions. The present model starts from this framework of within-firm delegation by incorporating the assumption that firms maximize a combination of profits and sales growth. In a period t a firm maximizes a utility $\left(u_{t}\right)$ function that comprises two elements: profit $\left(w_{t}\right)$ and sales growth $\left(s_{t}-s_{t-1}\right)$. Thus,

$$
u_{t}=w_{t}+\alpha\left(s_{t}-s_{t-1}\right)
$$

where $\alpha$ is a parameter that indicates the relative importance of the sales growth component. ${ }^{9}$ So, this paper applies Hannan \& Freeman's (1989) resistance-against-reorganization

\footnotetext{
${ }^{8}$ Rotemberg (1994) offers an interesting model in which unorthodox motives are introduced at the work floor, rather than the management level. Rotemberg, too, deviates from the 'extreme rationality' assumption by introducing what he calls 'rational altruism', which is well known from the work of Nobel Prize winner Gary Becker. The key finding is that a worker's altruism (tendency to cooperate) is rational (utility maximizing) if workers' payments depend upon joint profit. So, Rotemberg's setting is completely different from this paper's model. Rotemberg analyzes team work on the internal work floor of a firm, whereas the present paper focuses on managerial behavior in the face of external competition. However, the introduction of work floor behavior in a game-theoretic model of OE is an interesting avenue for future research.

${ }^{9}$ Note that both Van Lier \& Van Witteloostuijn (1993) and Van Witteloostuijn (1997) assume that a firm derives utility from absolute sales: i.e., $u_{t}=w_{t}+\alpha s_{t}$.
} 
argument to managers facing a downsizing option. In this paper's model, the parameter $\alpha$ reflects an aspect of Hannan \& Freeman's 'political costs' in the case of retrenchment. Managerial inertia plays a key role in the model by the essential driver $\alpha$, which represents the management's preference for high sales growth. With $\alpha>0$ this is clear from Equation (1): if the firm faces decline $\left(s_{t}-s_{t-1}<0\right)$, then $\alpha\left(s_{-}-s_{-1}\right)$ contributes negatively to utility, whereas the opposite occurs in times of growth [as then $s_{t}-s_{t-1}>0$, implying that $\alpha\left(s_{t}-s_{t-1}\right)>0$ ].

For the sake of simplicity, this paper is restricted to duopoly competition. ${ }^{10}$ Two firms compete over quantities (Cournot). Hence, firms decide on output only. Note that $s=0$ indicates exit. The inverse demand function is

$$
p_{t}=d_{t}-S_{t}
$$

which reflects a standard downward-sloping function with $\mathrm{p}$ denoting price, $\mathrm{d}$ being a demand size parameter and $S$ reflecting market supply (that is, the sum of the output volumes of firm $1, s^{1}$, and firm 2, s ). Equation (2) implies that the market price is negatively correlated with market supply (that is, demand increases if the market price falls, or vice versa). Note that $d$ is a proxy of OE's notion of carrying capacity: i.e., carrying capacity increases with d. Profit is $w=(p-c) s$, where $c$ denotes average cost and $(p-c)$ the profit margin. Substitution of the inverse demand function (2) into decision rule (1) determines a firm's output choice. That is, in a period $t+1$ firm i produces the output volume $s_{t+1}^{i}$ that maximizes

$$
u_{t+1}=\left(d_{t}-s_{t+1}^{i}-s_{t}^{j}-c^{i}\right) s_{t+1}^{i}+\alpha^{i}\left(s_{t+1}^{i}-s_{t}^{i}\right),
$$

where $i, j=1,2$ and $i \neq j$, and with the Cournot-Nash expectation that the rival will sustain the last period's output volume. Note that firm i's sales volume increases with carrying capacity (d) and firm i's downward inertia $\left(\alpha^{i}\right)$, and falls with the estimated sale volume of firm $j^{j}(s)$ and firm i's average cost $\left(c^{\prime}\right)$. This completes the model. Standard calculation of the Cournot-Nash solution gives the equilibrium values of output and profit for both firms. The Cournot-Nash equilibrium tool helps to calculate the firms' output decisions from which neither of the rivals is willing to depart, given the strategy of the opponent. The outcome is contingent upon the values of the parameters $d, \alpha^{1}, \alpha^{2}, c^{1}$ and $c^{2}$. Varying the values of these five parameters generates a large number of equilibria.

\section{Model outcomes}

By way of illustration, this paper discusses a limited number of specific classes of equilibria that shed new light on our understanding of the consequences of managerial inertia for

\footnotetext{
${ }^{10}$ The $n$-firm case is explored in Van Lier \& Van Witteloostuijn (1993). Basically, the results remain qualitatively identical when moving from a duopoly setting to Cournot competition with $n(n>2)$ firms.
} 
market competition and firm performance. ${ }^{11}$ Consider first Proposition 1 by focusing on the case of cost homogeneity $\left(c^{1}=c^{2}\right.$, implying that both firms are equally efficient) and favorable market demand (that is, $\mathrm{c}<\mathrm{d}$ ). The latter condition implies that in the standard Cournot duopoly equilibrium $\left(\alpha^{1}=\alpha^{2}=0\right)$ both firms operate profitably. The following two classes of equilibrium outcomes $(A-B)$ are particularly interesting.

A. If both firms are characterized by substantial managerial inertia, damaging competition occurs that drives profits toward or below zero, depending on the force of inertia. Although demand conditions reflect profit opportunities, price eventually falls below the level of average cost as a result of excessive market supply. Firm 1 is larger than firm 2 if $\alpha^{1}>\alpha^{2}$, and vice versa. Note that in the region where profit is positive for both firms (i.e., if $\alpha^{1}+\alpha^{2}<d-c$ ), the relatively more inert firm is also the more profitable one. The reason for this is that the relatively inert firm has higher sales than its relatively profit-maximizing rival, while both face an identical price-cost margin.

B. If firm $j$ is characterized by 'excessive' managerial inertia compared to its rival $\left(\alpha^{j}>>\alpha^{i}\right)$, the relatively flexible firm $i$ is expelled from the market and the inert firm $j$ survives. The reason is that firm i no longer perceives a viable niche due to the expansion of firm $\mathrm{j}$ : the inert firm $\mathrm{j}$ has expanded output beyond the profitable threshold (i.e., such that price, $p$, is below cost, c). Although market demand would enable two firms to produce profitably, even the surviving monopolist captures negative returns.

These two classes of equilibrium outcomes suggest that managerial inertia induces endogenous cut-throat competition, even in munificent environments. That is, environmental decline does not seem to be a necessary condition for cut-throat competition to occur, as is frequently assumed. In fact, the equilibrium outcomes of the game only change quantitatively, and not qualitatively, in the case of environmental decline. More specifically, the incidence of exit, as described in equilibrium class $B$, goes up if demand decreases $(d \downarrow)$ [and, for that matter, if cost increases $(\mathrm{c} \uparrow$ )]. Thus, the likelihood that a profit-maximizing firm will be expelled from the market by a managerially inert firm increases if demand decreases. When both firms prefer growth, both will stand the test of environmental decline, although the market is nonviable in terms of profitability (i.e., $c>d$ ). In that case, economic motives for operation are overruled by the force of managerial inertia.

Proposition 2 goes against the efficiency-favors-survival argument. In the model the efficiency argument is introduced by assuming that cost is asymmetric (i.e., $c^{i} \neq c$ ). Standard economic intuition predicts that the low-cost (efficient) firm will grow and/or survive. However, a re-analysis of the model with efficiency differences reveals that this is not necessarily the

\footnotetext{
${ }^{11}$ The present model differs substantially from previous 'nonprofit-maximizing' models on which it is based (Vickers, 1985; Fershtman \& Judd, 1987; and Sklivas, 1987) in two ways. First, it explores the consequences of between-firm differences in managerial inertia on equilibrium outcomes by introducing $\alpha$-asymmetry. Second, it explicitly incorporates firm exit (i.e., organizational mortality). As a result, the equilibrium outcomes presented in the present paper have, to our knowledge, not been explored elsewhere. Moreover, the current paper moves beyond Van Witteloostuijn (1997) by calculating the 'optimal' level of downward inertia (see Figure 1 below) and interpreting the model in terms of OE.
} 
case. The following two classes of equilibrium outcomes (C-D) are particularly illustrative.

C. Given favorable demand $(d>c)$, cost asymmetry $\left(c^{i}>d\right)$ associated with asymmetric managerial inertia $\left(\alpha^{i}>\alpha\right)$ results in a profit-making duopoly with an inefficient market leader, firm $\mathrm{i}$, and an efficient follower, firm $\mathrm{j}$.

D. If an inefficient firm $i$ is characterized by substantial managerial inertia compared to its rival $\left(\alpha^{i}>>{ }^{j} \alpha\right)$, the inefficient firm i drives out the efficient firm $j$. The result is an inefficient, managerially-inert, loss-making monopoly. The latter outcome is robust to changes in the demand regime (from favorable, $d>c$, to unfavorable, $d<c$ ).

The key finding here is that a relatively inert firm may outcompete a relatively flexible rival either by growing into the market leader or by expanding into a monopolist - even if the former faces a cost disadvantage (see also Ghemawat \& Nalebuff, 1985 \& 1990). Again, introducing strategic competition alone - that is, in a munificent demand environment - is sufficient to generate this result. Overall, the equilibrium classes A-D communicate the message that a profit-maximizing firm may be at a disadvantage if a rival 'blindly' pursues a sales-growthmaximizing strategy, even if the former is more efficient.

A final issue is that the model permits to calculate the 'optimal' level of flexertia (Van Lier \& Van Witteloostuijn, 1993). This is Proposition 3. That is, given the sales motivation of rival $j$ (reflected in $\alpha^{j}$ ) firm i can compute the level of managerial inertia (implied by $\alpha$ ) that maximizes profit or minimizes losses (and vice versa). Figure 1 illustrates this point.

\section{[Insert Figure 1 about here]}

First, take curve $\mathrm{I}$. In point $\mathrm{C}$ firm i captures maximum profits (or minimum losses in the case of curves II and III), wi, with the inertia-determining parameter $\alpha$ being fixed at $(d-c-\alpha) / 4$. The result is a profit if $c<d$ (that is, if the environment is favorable) and $\alpha^{j}<d-c$ (that is, if the rival does not drive strategic competition to the limit). Hence, for a specific range of values of $\alpha$ [i.e., from $\alpha^{\mathrm{L}}=0$ to $\alpha^{+}=(d-c-\alpha) / 4$ ] in Figure 1 firm i does not face a profit-growth tradeoff, provided that demand is favorable $(c<d)$ and rival $j$ is relatively flexible $\left(\alpha^{j}<d-c\right){ }^{12}$ That is, under specific circumstances firm i can increase the rate of profit and growth. Of course, the nature of the profit-growth linkage of firm i hinges upon the strategy of rival j. With decreasing demand (or increasing cost, for that matter) and/or reduced flexibility of firm $i$, the $w$ - $\alpha$ curve I in Figure 1 shifts to the south-west (cf. the curves II and III). Note, however, that for a reasonable range of parameter values $\left(c<d\right.$ and $\left.\alpha^{j}<d-c\right)$ a profit-maximizing level of managerial inertia can indeed be calculated.

The interpretation of the endogeneity or exogeneity of $\alpha$ is paradigm dependent. From an OE-perspective, $\alpha$ may be the result of imprinted routines, rules and procedures reflected in an organizational culture that 'urges' management to seek growth, even at the expense of profitability so as to avoid political costs. The observation that an organizational culture is

\footnotetext{
${ }^{12}$ Moreover, for $\alpha^{H}<\alpha^{i}<\alpha^{R}$ managerial inertia does also pay, albeit suboptimally.
} 
difficult to change, particularly if facing downsizing, is well established in the literature (Hofstede, 1991). Then, population dynamics will take care of the selection of firms with fitting $\alpha$ 's. So, the profit-maximization paradox is solved by Darwinian market selection, without the relatively inert firms being able to adapt their imprinted $\alpha$ 's to environmental contingencies. Selection thus operates on the $\alpha$-dimension (the degree of flexertia) rather than the $c$ dimension (relative efficiency). From a strategic choice and industrial organization angle, the adaptation argument would be emphasized. That is, $\alpha$ may be manipulated purposedly by designing an 'optimal' organizational structure or management compensation scheme. This is the way agency theory treats issues of managerial behavior. For example, Fershtman \& Judd (1987) and Sklivas (1987) examine the strategic advantage that can be derived from alternative compensation schemes. Basically, they show that owners can increase the profit of their firm in a Cournot setting, ceteris paribus, by paying the managers on the basis of obtained (absolute) profit and sales. That is, managers are paid $G=\beta P+(1-\beta) S$, where $G$ denotes the manager's salary, $P$ profit, $S$ sales and $0<\beta<1$. As in our model, the result is that firms behave more aggressively in the Cournot output game. So, the profit-maximization paradox is now solved by transferring the assumption of profit-maximizing behavior to the owners, rather than the managers, where profit-maximizing owners may install incentives that impose nonprofit-maximizing behavior upon their managers.

\section{APPRAISAL}

The aim of this paper was to demonstrate that considerable progress can be made concerning our understanding of the relationships between relative inertia, market competition and firm performance by integrating the conceptual richness of OE with the analytical rigor of IO's game-theoretic modeling. The main outcomes of the model presented above can be summarized as follows. First, managerial inertia through nonprofit-maximizing behavior may facilitate organizational survival, which is in support of the key argument of OE that relative inertia is a consequence of selection (Proposition 1). Second, an inefficient and inert - i.e., nonprofit-maximizing - firm may survive, notwithstanding the accumulation of losses, at the detriment of a relatively profit-motivated and efficient rival (Proposition 2). Third, knowing the sales motivation of the rival $i$, the profit-maximizing level of managerial inertia for firm $\mathrm{j}$ can be calculated (Proposition 3). This third finding is particularly interesting. In effect, this result goes halfway both extreme positions in the flexibility-inertia debate by suggesting that neither being inert (OE) nor being flexible (strategic choice theory) per se is the universal remedy against organizational failure, where the interpretation of the associated profit-maximization paradox is paradigm dependent. As the well-established contingency theory would suggest: it depends. That is, knowing the environmental conditions and the rivals' characteristics, a fitting level of inertia (or flexibility, for that matter) can be determined. This conclusion is nicely reflected in Hambrick and D'Aveni's (1988) study into organizational failure: neither strategic passivity (too much inertia) nor strategic hyperactivity (too much flexibility) enhances survival chances. The bottom line is that "[p]ure profit maximizing behavior may be at the expense of organizational 
survival" (D'Aveni, 1989b: 135). In our model this is because pure profit-maximizing firms are the likely victims of strategic competition, and in D'Aveni's (1989b) argument this follows from the status capital that is associated with prestigious but expensive managers.

As far as cut-throat competition is concerned, two important considerations are suggested by the model. First, the argument that firms should be flexible in the face of turbulent environments is indeed precarious, as our model reveals that managerial inertia may facilitate survival. It is important to stress, however, that in the present game highly inert firms survive at the detriment of profit-maximizing firms not without a cost: that is, the former are prepared to sacrifice profits, even to the extent of a long-run loss, for the sake of survival and large size. This outcome is not that surprising as revealing examples can be found of surviving companies that accumulate(d) losses for several years in a row (examples being General Motors in the U.S. and Hoogovens in The Netherlands). For an account of permanently failing organizations we refer to the interesting work of Meyer \& Zucker (1989). A number of additional real-world examples seem to reveal patterns that resemble the theoretical predictions of our model. In effect, our theoretical argument can be illustrated on the basis of the findings of Baden-Fuller (1989) in the UK steel castings market, of Sutton (1991) in food industries and of Van Witteloostuijn (1997) in the (petro)chemical industry. The studies of Baden-Fuller (1989) and Van Witteloostuijn (1997) reveal that exits originate by no means from the low-profitability (Baden-Fuller) or low-efficiency (Van Witteloostuijn) part of the market. That is, a substantial number of unprofitable (steel castings) and inefficient (petrochemicals) operations stayed in the market while (relatively) profitable and efficient opponents decided to close down. Additionally, data on the largest chemical companies in the world reveal that substantial differences prevail as to the firms' use of downsizing strategies (Van Witteloostuijn, 1997). Firms vary considerably in their downward adjustment of sales in times of a recession: i.e., a number of firms decreased sales in years of industry decline, whereas others even raised their sales volume in the same periods. Finally, Sutton (1991) - on the basis of a study in such industries as brewing, frozen food, and salt and sugar - reports that firms that started to escalate (sunk) advertising expenditures have grown into the current market leaders.

The observation that some firms sacrifice profits and even accumulate losses in order to survive complicates the extant debate on the appropriateness of different outcome measures to evaluate the success of individual companies. Two main outcome measures can be distinguished: efficiency (with its associated measures of financial performance) and mere survival. 10 and strategic choice theory (for example, strategic group analysis) are implicitly inclined to equate both outcome measures. More specifically, efficient and thus profitable firms will survive in the long run. As long as both measures are related, the debate on the appropriateness of different outcome measures is limited to its measurement properties. In that case, we agree that survival is preferable to efficiency because "[n]othing but the absolute test of survival is significant objectively" (Barnard, 1947: 70; see also Carroll \& Swaminathan, 1992). However, more fundamental questions, which have important ramifications for OE's selection theory, are raised if efficiency and survival are not necessarily - or sometimes even negatively - related. To be sure, OE recognizes that selection may operate on many 
dimensions such as efficiency and inertia (or flexibility), and that the target of evolution may change over time (Hannan \& Freeman, 1989). However, virtually nothing is known on these issues. Questions such as 'on which dimensions does selection operate?', 'in which circumstances does the target of evolution change?' and 'when does selection favor efficiency, inertia or both?' remain unanswered. It is clear that every selection theory, be it in the field of economics or sociology, should give priority to answering these questions.

In our view, game-theoretic modeling may contribute to our understanding of these issues by specifying the characteristics of surviving firms in equilibrium. Of course, for this purpose more complex models are needed than the one presented above. In this respect, a key limitation of our model is that the firm's profit constraint (or, to be precise, loss constraint) is infinitive. It is more realistic to assume that institutional restrictions limit the possibility to accumulate losses endlessly in order to remain big. For instance, following recent empirical studies on organizational decline (D'Aveni, 1989b \& 1989c), the influence of such restrictions can be introduced by modeling creditor's confidence. Moreover, the model can be extended in a number of other ways. First, in this paper's model, only retrenchment comes with a cost. However, expansion may be assumed to be costly, too. In the well-established IO-tradition on capacity competition, expansion (or exit) requires investment (or loss) of sunk cost in building up (or breaking down) productive capacity (Tirole, 1988). Second, other forms of inertia may be introduced, such as the escalation of advertising outlays. In that case, demand (d) is endogenized rather than fixed. In this respect, Sutton (1991) convincingly shows that modeling advertising outlays as an endogenous sunk cost leads to important insights as to the evolution of industry structure. It is possible that these model extensions will reveal other interesting equilibria not covered by the present model, such as inefficient and inert firms surviving at the detriment of efficient firms without incurring losses.

A second implication is that two forms of (cut-throat) competition should be distinguished: exogenous versus endogenous competition. Exogenous competition is caused by environmental dynamism - or, for that matter, relative shifts in the carrying capacity of populations - examples being a decline in demand as a result of shifting customer tastes or an increase in the density of a population following increased entry. Exogenous competition is therefore tantamount to increases in diffuse competition. Endogenous competition is the result of increases in direct rivalry among firms within a population in the form of strategic moves. The IO-literature suggests that these strategic moves, in turn, (should) induce organizational or managerial inertia (Dixit, 1982; and Ghemawat, 1991). More specifically, path dependence not only exists at the system level (Carroll \& Harrison, 1993) but also at the organizational and managerial level, as prior decisions or strategic moves affect current and future decisions or moves. Thus, strategic moves, inertia and path dependencies are intricately related. It is argued that these processes may have a profound impact on the extent of competition and therefore, eventually, on the structure of an entire industry or population. A first case in point is the important outcome of our model that a profit-maximizing firm is unlikely to survive when confronted with a managerially inert rival. The point is that if one firm develops a habit with respect to sustaining or building market share, the profit-maximizing firm has no choice but to follow the leader, providing it wants to survive. So, the inert firm induces 
cut-throat competition and erodes the profits of both firms. Another case in point is the escalation of competition in advertising-intensive industries, as described by Sutton (1991). Game-theoretic modeling with endogenous sunk (advertising) cost allows Sutton (1991) to formulate robust predictions as to the evolution of the structure of advertising-intensive industries. More specifically, the competitive escalation of advertising outlays in such industries inevitably leads to the survival of only a limited number of, heavily advertised, leading firms. Note that the escalation of advertising outlays is a specific form of path dependence or inertia.

Finally, in our view more effort is needed to integrate theories of diffuse (or exogenous) and direct (or endogenous) competition. Until now, OE has focused on diffuse competition and relative shifts in the carrying capacity of populations as the main trigger of organizational selection. We suggest that endogenous processes, shaped by inertia and path dependencies at the organizational or managerial level, may be as salient as exogenous processes in shaping the evolution of industries or populations. In any case, a theory of competition should incorporate both diffuse and direct processes (see also Hannan \& Carroll, 1992; and Singh, 1993). We are convinced that considerable progress can be made on this issue by crossfertilizing IO's insights on direct competition with OE's notions of diffuse competition. Here, we strongly believe that the game-theoretic methodology is the natural candidate to achieve this. 


\section{REFERENCES}

Alchian, A.A. (1950), Uncertainty, Evolution, and Economic Theory, Journal of Political Economy, 58, 211-221.

Amburgey, T.L., D. Kelly and W.P. Barnett (1993), Resetting the Clock: The Dynamics of Organizational Change and Failure, Administrative Science Quarterly, 38, 51-73.

Amburgey, T.L. and H. Rao (1996), Organizational Ecology: Past, Present, and Future Directions, Academy of Management Journal, 39, 1265-1286.

Baden-Fuller, C.W.F. (1989), Exit from Declining Industries and the Case of Steel Castings, Economic Journal, 99, 949-961.

Barnard, C.I. (1947), Functions of the Executive. Cambridge, MA: Harvard University Press.

Barnett, W.P. and T.L. Amburgey (1990), Do Larger Organizations Generate Stronger Competition, In J.V. Singh (Ed.), Organizational Evolution: New Directions. Newbury Park, CA: Sage, 78-102.

Barron, D.N., E. West and M.T. Hannan (1994), A Time to Grow and a Time to Die: Growth and Mortality of Credit Unions in New York City, 1914-1990, American Journal of Sociology, 100, 381-421.

Baum, J.A.C. (1996), Organizational Ecology, In S.R. Clegg, C. Hardy and W.R. Nord (Eds), Handbook of Organization Studies, London: SAGE, 77-114.

Baumol, W.J., J.C. Panzar and R.D. Willig (1982), Contestable Markets and the Theory of Industry Structure. New York: Harcourt, Brace, Jovanovich.

Boeker, W.P. (1988), Organizational Origins: Entrepreneurial and Environmental Imprinting at the Time of Founding, In G.R. Carroll (Ed.), Ecological Models of Organizations. Cambridge, MA: Ballinger, 33-52.

Boone, C. and A. van Witteloostuijn (1995), Industrial Organization and Organizational Ecology: The Potentials for Cross-fertilization, Organization Studies, 16, 265-298.

Burgelman, R.A. (1991), Intraorganizational Ecology of Strategy Making and Organizational Adaptation: Theory and Field Research, Organization Science, 2, 239-262.

Carroll, G.R. (1985), Concentration and Specialization: Dynamics of Niche Width in Populations of Organizations, American Journal of Sociology, 90, 1262-1283.

Carroll, G.R. and J.R. Harrison (1993), Evolution Among Competing Organizational Forms, World Futures, 37, 91-110.

Carroll, G.R. and A. Swaminathan (1992), The Organizational Ecology of Strategic Groups in the American Brewing Industry from 1975 to 1990 , Industrial and Corporate Change, 1, 65-97.

Cyert, R.M. and J.G. March (1963), A Behavioral Theory of the Firm, Englewood Cliffs, NJ: Prentice-Hall.

D'Aveni, R.A. (1989a), The Aftermath of Organizational Decline: A Longitudinal Study of the Strategic and Managerial Characteristics of Declining Firms, Academy of Management Journal, 32, 577-605.

D'Aveni, R.A. (1989b), Top Managerial Prestige and Organizational Bankruptcy, Organization Science, 1, 121-142.

D'Aveni, R.A. (1989c), Dependability and Organizational Bankruptcy: An Application of Agency and Prospect Theory, Management Science, 35, 1120-1138.

Dixit, A. (1982), Imperfect Competition and Public Policy: Recent Developments in Oligopoly Theory, American Economic Review, 72, 12-17.

Dyer, J.H. and W.G. Ouchi (1993), Japanese-Style Partnerships: Giving Companies a Competitive Edge, Sloan Management Review, Fall, 51-63.

Farrell, J. and G. Saloner (1986), Installed Base and Compatibility: Innovation, Product Preannouncements and Predation, American Economic Review, 76, 940-955.

Fershtman, C. and K.L. Judd (1987), Equilibrium Incentives in Oligopoly, American Economic Review, 77, 927-940. 
Frederickson, J.W. and A.L. laquinto (1989), Inertia and Creeping Rationality in Strategic Decision Processes, Academy of Management Journal, 32, 516-542.

Freeman, J. and M.T. Hannan (1990), Technical Change, Uncertainty, and Organizational Failure, Unpublished manuscript, Itaca, NY: Cornell University.

Friedman, M. (1953), Essays in Positive Economics. Chicago, IL: University of Chicago Press.

Fudenberg, D. and J. Tirole (1991), Game Theory. Cambridge, MA: MIT Press.

Ghemawat, P. (1991), Commitment: The Dynamic of Strategy. New York: Free Press.

Ghemawat, P. and B. Nalebuff (1985), Exit, RAND Journal of Economics, 15, 184-194.

Ghemawat, P. and B. Nalebuff (1990), The Devolution of Declining Industries, Quarterly Journal of Economics, 105, 167-186.

Gilbert, R.J. (1989), Mobility Barriers and the Value of Incumbency, In R. Schmalensee and R.D. Willig (Eds), Handbook of Industrial Organization. Amsterdam: North-Holland, 475-536.

Hall, M. (1967), Sales Revenue Maximization: An Empirical Examination, Journal of Industrial Economics, 15, 143154.

Hambrick, D.C. and R.A. D'Aveni (1988), Large Corporate Failures as Downward Spirals, Administrative Science Quarterly, 33, 1-23.

Hannan, M.T. and G.R. Carroll (1992), Dynamics of Organizational Populations: Density, Legitimation and Competition. New York: Oxford University Press.

Hannan, M.T. and J. Freeman (1977), The Population Ecology of Organizations, American Journal of Sociology, 82, 929-964.

Hannan, M.T. and J. Freeman (1984), Structural Inertia and Organizational Change, American Sociological Review, $49,149-164$

Hannan, M.T. and J. Freeman (1989), Organizational Ecology. Cambridge, MA: Harvard University Press.

Haveman, H. (1990), Diversification, Performance, and Mortality, Unpublished manuscript, Durham: Duke University.

Haveman, H. (1993), Organizational Size and Change: Diversification in the Savings and Loan Industry after Deregulation, Administrative Science Quarterly, 38, 20-50.

Hofstede, G.H. (1991), Cultures and Organizations: Software of the Mind, London: McGraw-Hill.

Hrebiniak, L.G. and W.F. Joyce (1985), Organizational Adaptation: Strategic Choice and Environmental Determinism, Administrative Science Quarterly, 30, 336-349.

Jensen, M.C. and K.J. Murphy (1990), Performance Pay and Top Management Incentives, Journal of Political Economy, 98, 225-264.

Johnson, G. and K. Scholes (1993), Exploring Corporate Strategy: Text and Cases. Englewood Cliffs, NJ: PrenticeHall.

Katz, M. and C. Shapiro (1985), Network Externalities, Competition and Compatibility, American Economic Review, $75,424-440$.

Katz, M. and C. Shapiro (1986), Technology Adoption in the Presence of Network Externalities, Journal of Political Economy, 94, 822-841.

Kelly, D. and T.L. Amburgey (1991), Organizational Inertia and Momentum: A Dynamic Model of Strategic Change, Academy of Management Journal, 34, 591-612.

Lackman, C.L. and J.L. Craycroft (1974), Sales Maximization and Oligopoly: A Case Study, Journal of Industrial Economics, 23, 81-95. 
Lambert, R.A., D.F. Larcker and K. Weigelt (1991), How Sensitive is Executive Compensation to Organizational Size, Strategic Management Journal, 12, 395-402.

Lier, A. van and A. van Witteloostuijn (1993), Big is Beautiful: Cournot Competition, Habit Formation, and Exit, Research Memorandum RM 93-016, Maastricht: University of Limburg.

Machlup, F. (1967), Theories of the Firm: Marginalist, Behavioral, Managerial, American Economic Review, 57, 1-33.

Meyer, M.W. and L.G. Zucker (1989), Permanently Failing Organizations. Newbury Park, CA: Sage.

Miles, R.E. and C.C. Snow (1984), Fit, Failure and the Hall of Fame, California Management Review, 26, 10-28.

Miles, R.E. and C.C. Snow (1992), Causes of Failure in Network Organizations, California Management Review, 34 , 53-72.

Morck, R.A., A. Shleifer and R.W. Vishny (1990), Do Managerial Objectives Drive Bad Acquisitions, Journal of Finance, 45, 31-48.

Nelson, R.R. and S.G. Winter (1982), An Evolutionary Theory of Economic Change. Cambridge, MA: Belknap Press.

Panzar, J.C. (1989), Technological Determinants of Firm and Industry Structure, In R. Schmalensee and R.D. Willig (Eds), Handbook of Industrial Organization, Amsterdam: North-Holland, 3-59.

Peck, M.J. (1988), The Large Japanese Corporation, In J.R. Meyer and J.M. Gustafson (Eds), The U.S. Business Corporation: An Institution in Transition, Cambridge, MA: Ballinger, 35-36.

Péli, G., J. Bruggeman, M. Masuch and B. Ó. Nualláin (1994), A Logical Approach to Formalizing Organizational Ecology, American Sociological Review, 59, 571-593.

Powell, W.W. (1990), Neither Market nor Hierarchy: Network Forms of Organization, Research in Organizational Behavior, 12, 295-336.

Quinn, J.B. (1978), Strategic Change: Logical Incrementalism, Sloan Management Review, Fall, 7-21.

Robbins, S.P. (1993), Organizational Behavior. Englewood Cliffs, NJ: Prentice-Hall.

Rotemberg, J.J. (1994), Human Relations in the Workplace, Journal of Political Economy, 102, 684-717.

Scherer, F.M. and D. Ross (1990), Industrial Market Structure and Economic Performance. Boston: Houghton Mifflin.

Schmalensee, R. (1989), Inter-industry Studies of Structure and Performance, In R. Schmalensee and R.D. Willig (Eds), Handbook of Industrial Organization. Amsterdam: North-Holland, 951-1010.

Schmalensee, R. and R.D. Willig (Eds) (1989), Handbook of Industrial Organization. Amsterdam: North-Holland.

Shapiro, C. (1989), Theories of Oligopoly Behavior, In R. Schmalensee and R.D. Willig (Eds), Handbook of Industrial Organization. Amsterdam: North-Holland, 329-414.

Shleifer, A. and R.W. Vishny (1988), Value Maximization and the Acquisition Process, Journal of Economic Perspectives, 2, 7-20.

Singh, J.V. (1993), Review Essay: Density Dependence Theory - Current Issues, Future Promise, American Sociological Review, 99, 464-473.

Singh, J.V. and C.J. Lumsden (1990), Theory and Research in Organizational Ecology, Annual Review of Sociology, 16, 161-195.

Sklivas, S.D. (1987), The Strategic Choice of Managerial Incentives, RAND Journal of Economics, 18, 452-458.

Spencer, B.J. and J.A. Brander (1992), Pre-Commitment and Flexibility: Applications to Oligopoly Theory, European Economic Review, 36, 1601-1626.

Strategic Management Journal, 1988, 9, 1-140. 
Strategic Management Journal, 1991, 12, 1-155.

Sutton, J. (1991), Sunk Costs and Market Structure: Price Competition, Advertising and the Evolution of Concentration. Cambridge, MA: MIT Press.

Swaminathan, A. and J. Delacroix (1991), Differentiation within Organizational Populations, Academy of Management Journal, 34, 679-692.

Tirole, J. (1988), The Theory of Industrial Organization. Cambridge, MA: MIT Press.

Vickers, J. (1985), Delegation and the Theory of the Firm, Economic Journal, 95, 138-147.

Whetten, D.A. (1987), Organizational Growth and Decline Processes, Annual Review of Sociology, 13, Reprinted in K.S. Cameron, R.I. Sutton and D.A. Whetten (Eds), Readings in Organizational Decline: Frameworks, Research, and Prescriptions, 1988, Cambridge, MA: Ballinger, 27-44.

Winter, S.G. (1990), Survival, Selection, and Inheritance in Evolutionary Theories of Organization, In J.V. Singh (Ed.), Organizational Evolution: New Directions. Newbury Park, CA: Sage, 269-297.

Winter, S.G. (1975), Optimization and Evolution in the Theory of the Firm, In R.H. Day and T. Groves (Eds), Adaptive Economic Models. New York: Academic Press, 73-118.

Witteloostuijn, A. van (1997), Bridging Behavioral and Economic Theories of Decline: Organizational Inertia, Strategic Competition and Chronic Failure, Research Memorandum, Maastricht: NIBOR/University Maastricht, forthcoming in Management Science, 43. 
FIGURE 1

Profit-maximizing level of managerial inertia 